\title{
合成有機化学亡 発酵化学
}

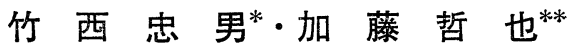 \\ Collaborative Study of Synthetic Organic Chemistry and \\ Microbiology in Chemical Industry.
}

Tadao TAKenishi* and Tetsuya KATO**

\section{I. はじめに}

化学工業の中で微生物化学々有機化学の接する領域は きわめて多角的である。この多彩な分野の中で，第一の 局面に組み合わせを特長とするプロセスがとり上げられ る。アスコルビン酸, プレドニソン, コーチゾンなどの 製造工業は, 合成化学々微生物のそれぞれ高度の選択性 をもつ反応が組合わされ，長い間秀れた経済性をもつ製 造プロセスとして知られてきた。このような組合わせの プロセスの延長線上に最近では核酸系調味料の製造工業

* 味の素(株)開発企画室 (

** 味の素(株)中央研究所

* Ajinomoto Co., Inc., Planning and Development Dept.

** Ajinomoto Co., Inc., Central Research Laboratories

\section{略語}

$\mathrm{CoA}$ : 補酵素A

TPN：トリホスホピリジンヌクレオチド TPNH 還元型, $\mathrm{TPN}^{+}$酸化型

ATP : アデノシン三リン酸

IMP : 5'-イノシン酸

$\mathrm{XMP}: 5^{\prime}$-キサンチル酸

GMP : 5'-グアニル酸

AMP : 5'-アデニル酸

SAMP : スクシニルアデニル酸

AICAR : 5-アミノ-4-カルバモイル-1-( $\beta$ リリボフラ

$$
\text { ノシル)ーイミダゾール }
$$

SAICAR : 5-スクシニルアミノ-4-カルバモイル-1-

$$
\text { ( } \text { ーリボフラノシル)-イミダゾール }
$$

$\mathrm{NAD}:$ ニコチンアミドアデニンジヌクレオチド

NADH : 同還元型
が登場した。この合理的なプロセスによって驚くような 急テンポで核酸系調味料の製造コストが下がり，ひろく 食品加工や家庭の食卓に普及していった"1)。

第二の局面は発酵原料としての石油化学製品の進出で ある。グルタミン酸発酵はいよいよ糖質から酢酸に原料 転換し始めて, 石油化学関連製品が発酵原料として大量 消費される時代がきりひらかれた。アミノ酸工業では今 まで合成有機化学と微生物化学が競って互に刺激しあい 著しく生産性を高め, アミノ酸の市場を拉大するために 役立ってきた 2)。 L-グルタミン酸は 1968 年わが国で約 10 万 $\mathrm{t}$ 生産され, そのらち約 1 万 $\mathrm{t}$ 程度が 合成法によ るものである。

DL-メチオニン, L-リジン, グリシンについては工業 的規模で合成法が採用されたが，Lーリジンは最近中止さ れ3), 現在は発酵法だけによって工業生産が行なわれて いる。飼料用としてのアミノ酸の需要は将来大きな発展 が期待されるが，高リジントウモロコシ4), 高リジン大 むぎ5)などが続々と開発されているので農産物との競合 も激しい。リジンは将来 $40 \phi / \mathrm{lb}$ にならなければ競争で きないともいわれている4)。図 1 にグルタミン酸原料の 価格の推移を示した。原料価格の将来性の推移とタイミ ングに合った技術開発能力によって経済的成功をおさめ た例といえよう（図 1)。

第 3 の局面として微生物を有機化合物の助けを借りて 生育条件を変えたり，あるいは菌株そのものを遺伝的に 改良する問題がある。発酵化学では今後も炭素源の資化 性，生産物の特異性を目ざして天然界からいろいろな新 菌が採集されたり, 同時に菌株の馴化, 改良も進められ よう。細菌の菌体は精巧な複合触媒であり, その内には 高次に組合わされた酵素反応が逐次進行するが，反応経 路を自ら制御するためのフィードバック回路がそなえら 


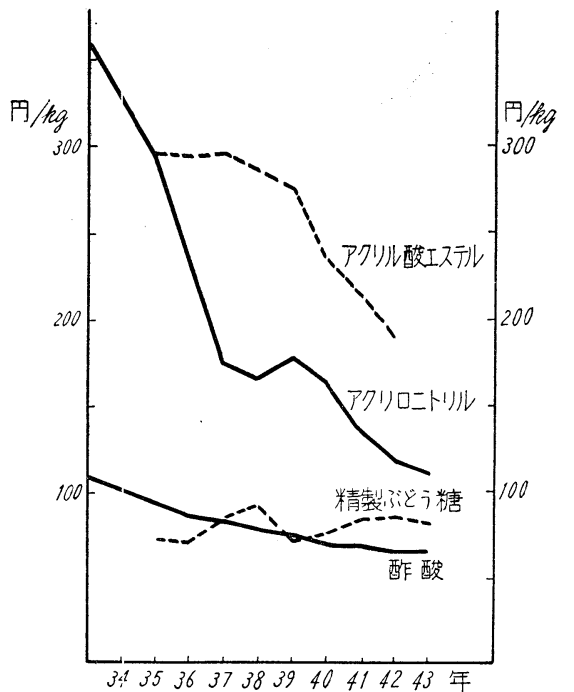

図 1 MSG 原料関連品の価格推移 （通産省，食料庁等の統計による）

れている。このような微生物の代謝過程を生化学的手法 で人為的に制御するために, 代謝経路を遮断し, 他方調 節機構の解除方必要になる。微生物を突然変異により酵 素系の一部を次失した，いわゆる栄養要求変異株を使 い，代謝調節党支配する成分 key nutrient を制限条件で 培養させ, 有用な代謝中間体を蓄積させる技術が発達し た。生物の突然変異が分子の反応レベルで解明され，細 菌の培養液に㧍とした一滴の変異誘起剤が一個の遺伝暗 号トリプレットで 7 種類の違った変化をひき起すことが 知られている。

目的物質に似た化学構造をもつ拮抗物質を使い，生合 成系の調節回路が遺伝的に改質されたいわ河るアナログ 而性変異株にも有力なアミノ酸生産菌がある。Brevibacterium flavum の $\alpha$-アミノ $\beta$-オキシ吉草酸耐性変異 株で糖質, 酢酸を原料として直接 スレオニンを蓄積する方法(6) や， $S-2-$ アミノエテル-L-システイン 耐性変異株による L-リジンの蓄 積つなどがある。酵素の基質特異 性の解明と共に，より選択的な拮 抗物質が開発ざれるね゙ならない。 菌株の改良々同時に培養時の条件 をコントロールして，細胞膜を蓄 積物が透過し菌体外に分泌し易くすることも重要であ る。生育中に細胞膜構造を変化させる目的で, 界面活性 剤8)やペニシリン9などを培地に添加することが行な われている。

最近の遺伝機構の解明は目ざましく，生物の種の特異
性を規制するタンパクのアミノ酸配列の遺伝機構が分子 レベルで理解されるようになった。現在遺伝子 DNAの 全合成に意欲的にとり組むウィスコンシン大学のコラナ 教授は有機合成反応と酵素反応を組合わせた精譈な計画 ですでにその可能性を示した ${ }^{10)}$ 。細胞の遺伝子から特定 の DNA を引き出すことは困難であるが，微生物ではた とえば，七ラチア属に大腸菌の遺伝子を導入させてアル カリホスファターゼを合成させた例がある。微生物の改 良だけでなく，すでに薬理遺伝学とか行動遺伝学などの

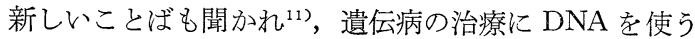
いわば，生命の改造も夢物語でなく考えられている。核 酸の合成法が飛躍的に進歩すれば，この分野に寄与する 力はきわめて大きい。

生物の進化を探究するときにも，異なる生物種の間で ある種のタンパク質のアミノ酸配列が比較される。

この様な研究から地球上の生命があらわれてからの進 化の経過が仮定され，さらに飛躍して他の惑星で生命が 存在するか否か, 生命のない状態での化学的進化の様相 がどんなものかが推論されている。原始の海で最初の有 機物質の出現について色々な角度から研究されている が，これらの研究から派生した新しい応用に，工業的な アデニンの合成，シトシンアラビノシドの合成がある。

以上のべた 3 つの局面から最近の微生物化学々有機化 学のトピックスをまとめた。

\section{C-O 結合生成における発酵と合成}

1. 脂肪族炭化水素の生化学的酸化 炭化水素を液 相自動酸化開裂して脂肪酸を合成する工業はドイツに始 めておこり, ソ連で発達して 20 年になる。最近では液 状パラフィンから 2 級アルコールの合成がアメリカやソ 連で工業化されている ${ }^{12)}$ (図 2)。

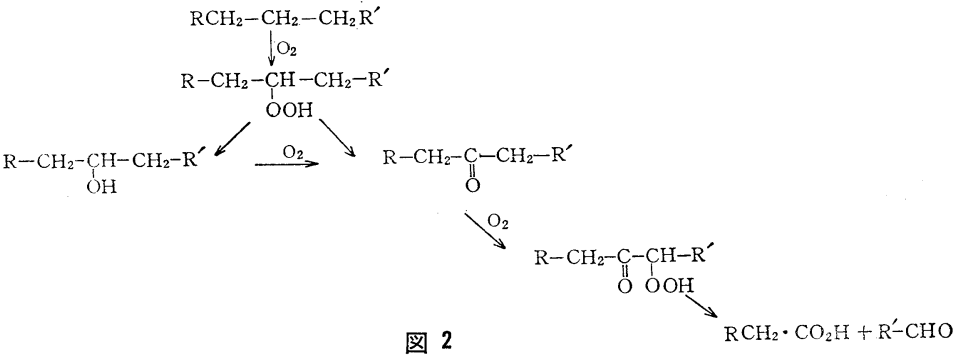

微生物酸化で注直鎖パラフィンの末端メチルが酸化さ れる。一端の酸化でモノカルボン酸 ${ }^{13)}$, 両端から酸化 されるときには，ジカルボン酸ができ14)，ともに炭素 の損失なく，もとの炭素数のカルボン酸が合成される (図 3)。 
$\mathrm{C}_{10} \mathrm{n}$-alkane $\begin{gathered}\text { Condida rugasa } \\ \mathrm{C}_{10} \text { mono carboxylic acid }\end{gathered}$ 図 3

2 級炭素をもつ分枝パラフィンを資化する微生物では メチルケトンが生成し，3 級炭素の場合には酸化がとま り 3 級アルコール ${ }^{15)}$ が生成する。シクロヘキサン環の酸 化ではエチルシクロヘキサンから trans-4-エチルシクロ ヘキシルアルコールが生成する ${ }^{16)}$ 。

※-オレフィンからはジオールができる場合と ${ }^{17)}$, 末端 メチルが酸化される場合とがある ${ }^{18)}$ 。後者の例ではへキ サデセンからパルミチン酸 15-ヘキサデセニルが生成す ることが確認されている。パルミチン酸は 15-ヘキサデ セノールからか, 一たん $\beta$-酸化分解後 CoA による生合 成系で再合成されたものか明らかでない。またアルデヒ ドを Pseudomonas 属の菌体からとり出した酵素でカル ボン酸を得る方法がある ${ }^{199}$ 。パラアルデヒドを資化する 微生物も知られており ${ }^{20)}$, 工業的に有用な物質が蓄積さ れる可能性もあろう。

飽和脂肪酸の脱水素反応に関与する酵素系は炭素鎖長 による特異性がつよい21)。Corynebacterium diphtheriae により, ステアリン酸からオレイン酸, パルミチン酸か ら cis-9-ヘキサデセン酸ができる ${ }^{22)}$ 。 $\mathrm{C}_{9}, \mathrm{C}_{10}$ の4 個の 水素のうち引きぬかれる 2 個は末端カルボキシルに対し て立体特異的である ${ }^{23)}$ (図 4)。

$$
\begin{array}{r}
\text { stearate }+\mathrm{CoA}+\mathrm{ATP} \longrightarrow \text { stearyl-CoA } \\
\text { stearyl-CoA }+\mathrm{O}_{2}+\mathrm{TPNH}+\mathrm{H}^{+} \\
\longrightarrow \text { oleyl-CoA }+\mathrm{TPN}^{+}+2 \mathrm{H}_{2} \mathrm{O}
\end{array}
$$

図 4

現在化学工業ではエチレンから天然物と変らぬ偶数炭 素の高級アルコールや, 脂肪酸が Ziegler 法で合成され ており，これらを選択的な微生物反応で不飽和脂肪酸に 変える可能性もあろら。

不飽和脂肪酸の生合成系には嫌気的条件でも可能な経 路があり, CoA で C 鎖の延長する過程で $\beta$-オキソ酸が 合成され, さらに還元脱水して不飽和酸が生成する場合 もある。

2. 芳香族炭化水素の生化学的酸化 多数の芳香族 化合物が農薬などに使われている。もしもこれらが土㗒 中で微生物によって分解されなかったら芳香族の蓄積は 周囲の環境におよび, さらには動物組織に入りこむであ ろら。しかし土壤中の微生物で芳香族の資化能があるも のは数多く, その分解機構もしだいに明らかになってき た。ベンゼン環の開裂は 2 通りあることが知られてい

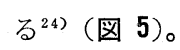

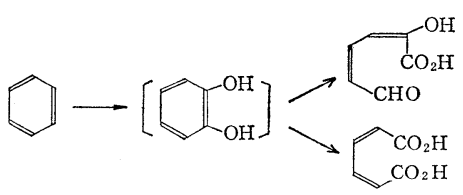

図 5

nーアルカンを炭素源に生育する Nocardia 属の一菌株 は培地に加えられたモノアルキルベンゼンを酸化して, フェニル酢酸, フェニルプロピオン酸を生成する ${ }^{25}$ （図 6)。

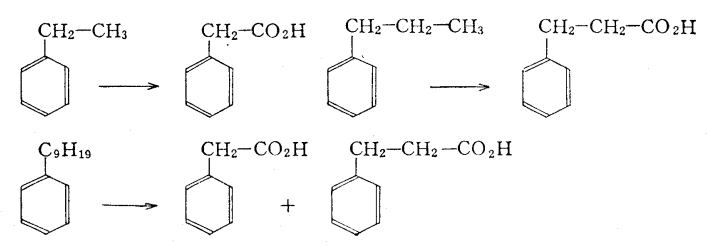

図 6

p-シメン，o-, $m$ - および $p$-キシレンの酸化を(図 7) に示す ${ }^{26) 。 ~}$<smiles>Cc1ccc(C(C)C)cc1</smiles><smiles>Cc1cccc(C(=O)O)c1</smiles><smiles>CC1CCC(C)C(C(=O)O)C1C(=O)O</smiles>

図 7

Pseudomonas の一菌株によって 側鎖と共に 芳香環が 酸化されることが知られている
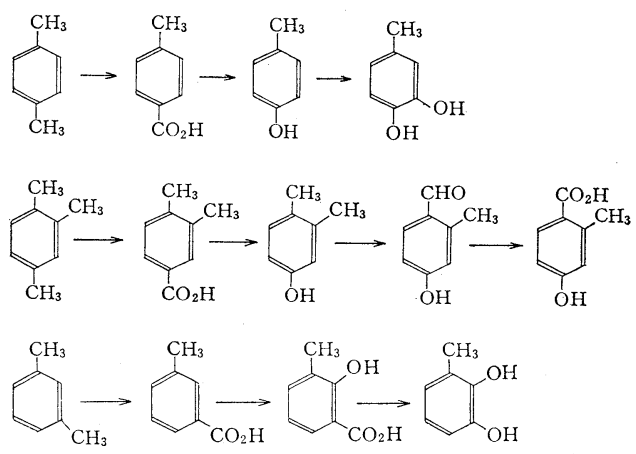

図 8

カテコールを経て芳香環はさらに酸化開裂し資化され $る^{30)}$ (図 9)。 

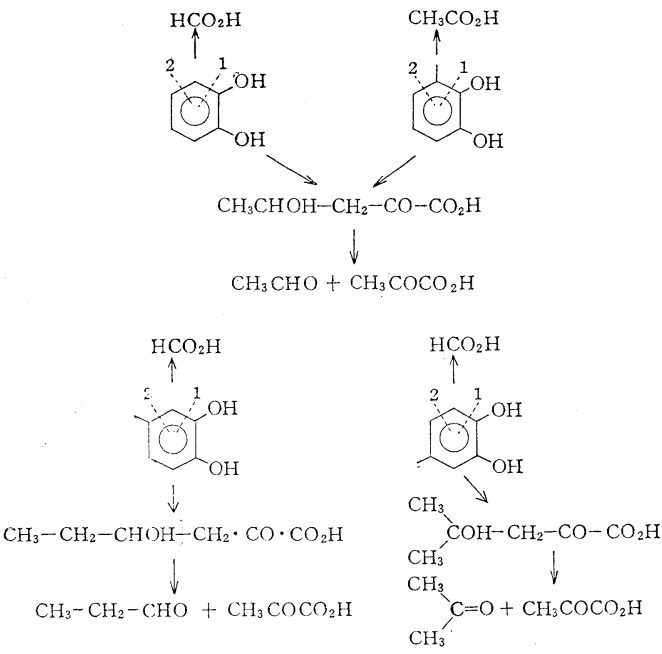

図 9 Pseudomonas 属による芳香族の酸化開裂 2 ……. は開裂する順序を示す

Nocardia 属の菌株で p-キシレンから $\alpha, \alpha$-ジメチル ムコン酸が生成する ${ }^{31}$ ) (図 10)。<smiles>Cc1cccc(C)c1</smiles>

図 10

芳香族を酸化分解する能力が見られない菌株でも基質 として芳香族が添加されると酸化酵素が誘導されて資化 する能力があらわれることがある。しかし芳香族の置換 基数が增すと微生物によって酸化されにくくなり，置換 基と核の酸化を選択して行なわせることが困難のようで ある。

ナフタレンを資化してサリチル酸を生成する場合は数 多く研究され，転化率 85～95\%，濃度 2～4\% まで蓄積 できた例が知られている ${ }^{32)}$ 。ナフタレンを基質としてグ ルタミン酸を蓄積した例も知られている ${ }^{33) 。 ~}$

芳香族炭化水素の資源としてはナフサの熱分解により $\mathrm{C}_{2 \sim 5}$ オレフィンを 生産するときに副生する分解油があ る。特徴としてベンゼンの含量が高く, エチルベンゼン も比較的多い。またナフサの接触改質油はトルエン，キ シンンの資源として使われている。クエートやイラン産 原油の 重質ナフサ $\left(100 \sim 200^{\circ} \mathrm{C}\right)$ 留分 ${ }^{34)}$ はナフテン 20 〜 40\%，芳香族 15２5\% を含み，白金一アルミナ系触 媒の接触改質度応で $\mathrm{C}_{6 \sim 10}$ 芳香族の含量は 50〜70\%に 達する（表 1)。

アルキル基は $n>\sec \fallingdotseq i>$ tert 2 で 2 置換体はメタ体

表 1 石油系芳香族の組成 $(\%)$

(雨宫 石油と石油化学 11 (1) 41 (1967)

\begin{tabular}{|c|c|c|c|c|}
\hline & & & 接触改質油 & ナフサ分解油 \\
\hline & ン ゼ & ン & $3 \sim 6$ & $15 \sim 30$ \\
\hline$\vdash$ & ルエ & ン & 20 & 15 \\
\hline キ & シ レ & ン & 20 & $10 \sim 20$ \\
\hline & EB & & 2 & 6 \\
\hline & $p-\mathrm{X}$ & & 4 & $1 \sim 2$ \\
\hline & $m-\mathrm{X}$ & & 10 & $2 \sim 5$ \\
\hline & $o-\mathrm{X}$ & & 4 & $1 \sim 3$ \\
\hline & $\mathrm{C}_{9}$ & & 8 & 8 \\
\hline & $\mathrm{C}_{10}$ & & 2 & $<1$ \\
\hline
\end{tabular}

が多い。 $\mathrm{C}_{9} 9$ 種， $\mathrm{C}_{10}$ では 25 種の置換体の混合物が確 認されている。将来すぐれた選択酸化能をもつ微生物が 出現すると改質油留分を綜合的に利用できる可能性もあ ろう。

3. その他 微生物がメチルエチルケトン, アセト ニトリル ${ }^{35)}$ ，シアンを資化 ${ }^{36,37)}$ して生育することも知ら れている。

シアンを分解する機構として, シアンの分解はチトク ローム系酸化酵素を阻害するが, 微生物がシアンに適応 しシアン不感受性の電子伝達系を形成し, シアンの分解 は redox 系を経て $\mathrm{CO}_{2}, \mathrm{NH}_{3}$ まで分解すると考えられ ている。

$\mathrm{C}-\mathrm{O}$ 結合の生成反応として特殊な例に 水酸基のアル

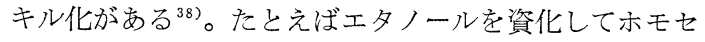
リンを蓄積する多くの微生物により，O-エチルホモセリ ンが得られ, 種々のアルコールの存在で, それぞれ Oアルキルホモセリンがえられている（図 11）。

$$
\begin{gathered}
\mathrm{EtOH} \longrightarrow \mathrm{HOCH}_{2}-\mathrm{CH}_{2}-\mathrm{CH}-\mathrm{CO}_{2} \mathrm{H}, \\
\mathrm{NH}_{2} \\
\mathrm{EtOCH}_{2}-\mathrm{CH}_{2}-\mathrm{CH}-\mathrm{CO}_{2} \mathrm{H} \\
\mathrm{NH}_{2}
\end{gathered}
$$

図 11

\section{III. 生合成系における $\mathbf{C}-\mathbf{C}$ 結合の生成反応}

微生物の代謝系でとりこまれる有機化合物には石油化 学から合成される, アルコール，グリコール，カルボニ ル化合物などがある（図 12）。たとえばエチレンから誘

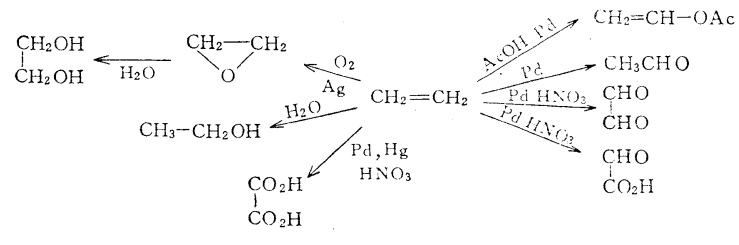

図 12 
導されるエタノール，酢酸などを資化して種々のアミノ 酸が蓄積されている。

微生物の酵素系で C-C 結合を生成する反応は糖質の 代謝系に代表されるよらな活性メチレン化合物やカルボ ニル化合物間の反応である。現在知られている酵素反応 を化学反応との関連のもとにみると興味深い。

1. アセチル Co-A の関与する 酵素反応 アセチ ル Co-A とグリオキシル酸の縮合反応は E. coli の代謝 系で見出された ${ }^{39)}$ 。プロピオン酸や酪酸を唯一の炭素源 として培養した E. coli から，それぞれの有機酸のアシ ル Co-A とグリオキシル酸との縮合物が見出されてい る $^{40)}$ (図 13)。

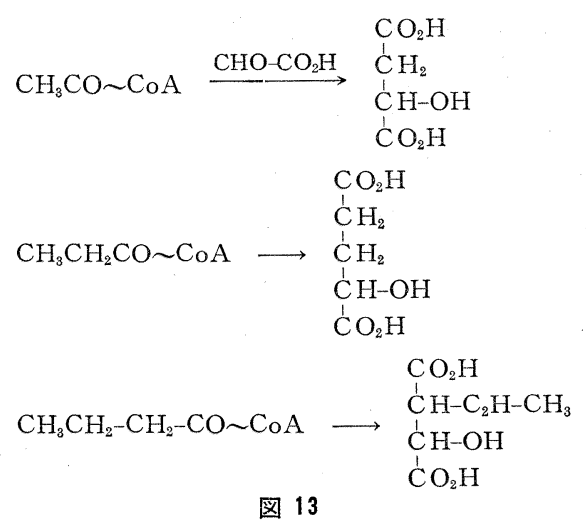

アセチル $\mathrm{CoA} と ロ$ とキソ酸の反応には重要な反応が 多以(図 14)。

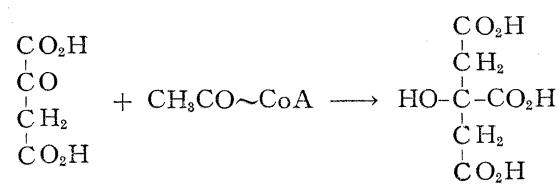

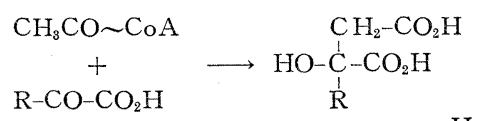

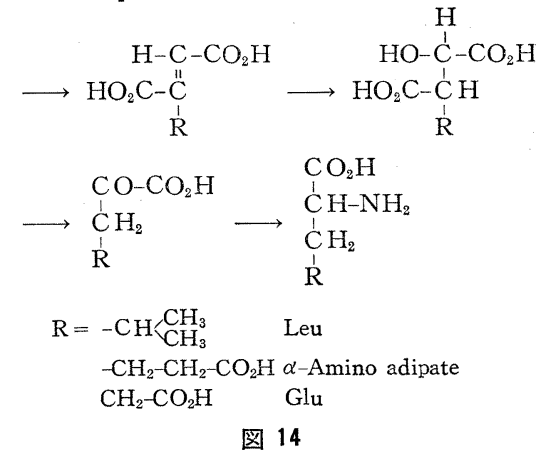

図 14

2. ピルビン酸の関与する反応 ピルビン酸とアセ

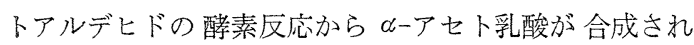

るが，アルキル基の転位で なり，さらにバリンにかわる。

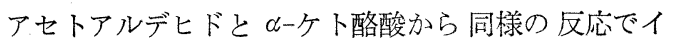
ソロイシンが生成することが Torulopsis utilis に見出 されている41) (図 15)。

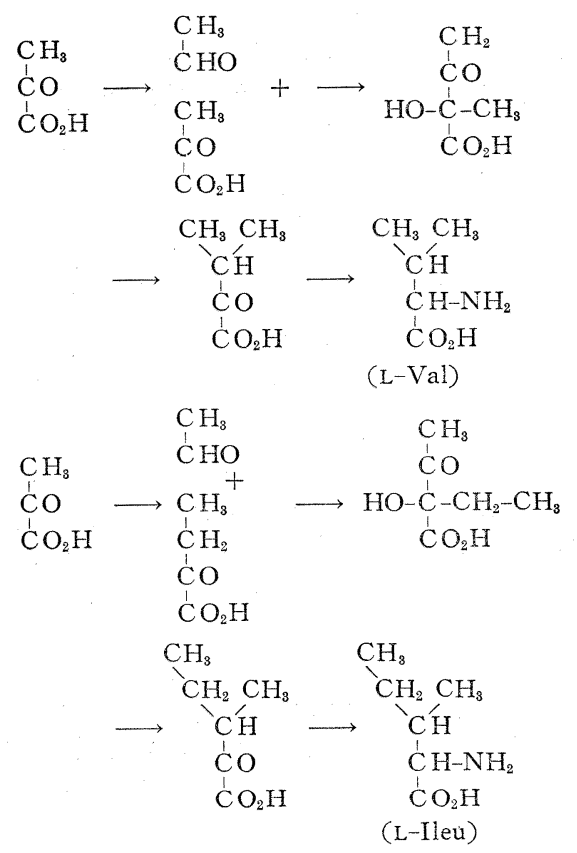

図 15

3. マロニル CoA の関与する反応 マロニル CoA とアセチル $\mathrm{CoA}$ から, ブチリル $\mathrm{CoA}$ ができ, さらにマ ロニル CoA がつぎつぎに加わって炭素 2 個ずつ増した 脂肪酸ができてくる(図 16)。

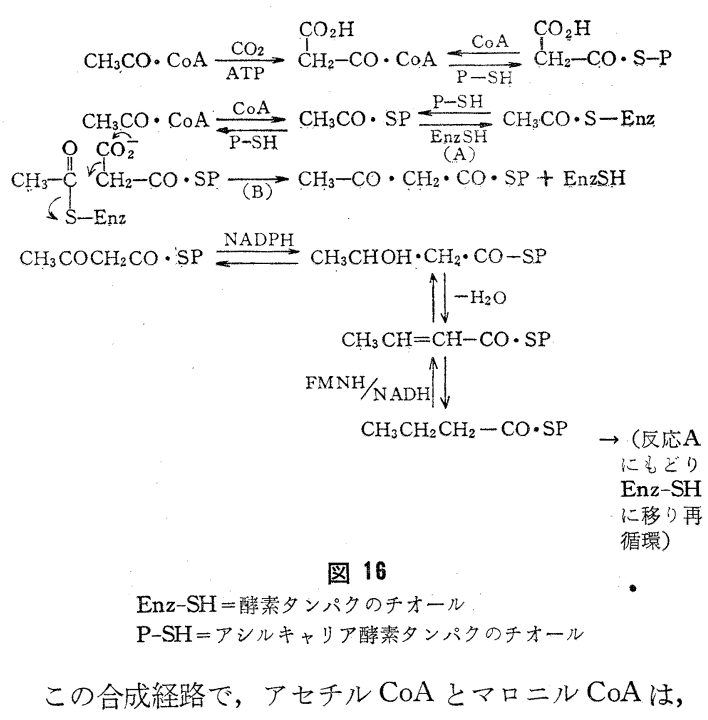


特定のタンパクの相当するチオールエステルに変換され る。

このようにして生成したアセチルプロテインとマロニ ルプロテインが反応して 1 モルの酵素タンパクと $\mathrm{CO}_{2}$ とを遊離させ, キャリアのアセトアセチル誘導体が合成 される。このものは次の還元段階でブチリルプロテイン に変換され，洁局 $\mathrm{C}_{16}$ または $\mathrm{C}_{18}$ までくり返される。
4. $\mathbf{C}_{1}$ の導入による $\mathbf{C}-\mathbf{C}$ 結合の生成 $\mathrm{C}_{1}$ 単位で $\mathrm{C}-\mathrm{C}$ 結合の生成する 酵素反応は葉酸が関与する。グリ シンの合成, グリシンにオキシメチル基の導入によるセ リンの合成, ウラシル塩基にメチル基を導入するチミン の合成などが:主な酵素反応である（図 17）。
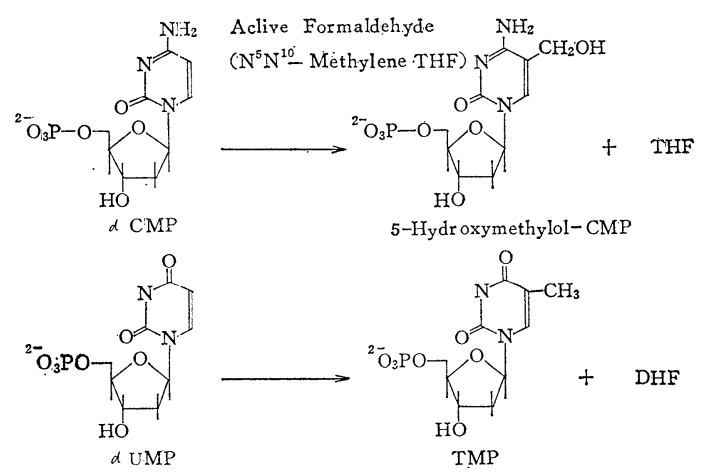

$$
\prod_{\mathrm{CO}_{2} \mathrm{H}}^{\mathrm{CH}_{2}-\mathrm{NH}_{2}} \longrightarrow \begin{aligned}
& \mathrm{CH}_{2}-\mathrm{OH} \\
& \mathrm{C} H-\mathrm{NH}_{2} \\
& \mathrm{CO}_{2} \mathrm{H}
\end{aligned}+\mathrm{THF}
$$

$\mathrm{DHF}=7,8$-dihydrofolate

$\mathrm{THF}=5,6,7,8$-tetrahydrofolate

微生物のトリテルペノイド，ステロイドなどの二重結 合に $\mathrm{C}_{1}$ が導入されるときには, $S$-アデノシルメチオニ ンのメチル基が $S$-イリド型で導入されると考えられて いる ${ }^{42)}$ (図 13)。

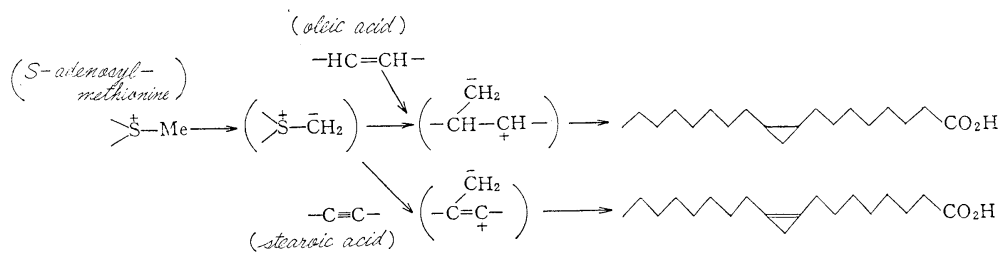

図 18

乳酸菌の生戎する脂肪酸から, シクロプロパン環, カ ポック油から、シクロプロペン環のある脂肪酸が見出さ れている。

\section{C-N 結合生成における発酵と合成}

4. $\boldsymbol{\alpha}, \boldsymbol{\beta}$-不飽和酸からアミノ酸の生成 フマル酸 を原料として E. coli を使用する L-アスパラギン酸の
製造法はよく知られている。これは利用される生合成系 が単純なので，原料からの転換がほとんど $100 \%$ で，収 率よく目的物が得られる例である ${ }^{43}$ （図 19）。同様な条 件下で桂皮酸から 18\% の収率でフェニルアラニンも得 られている44)

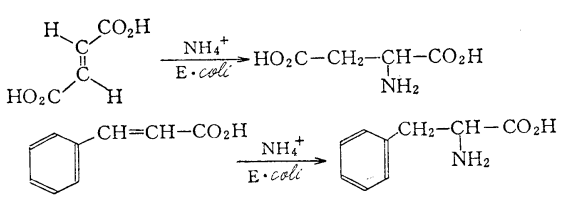

図 19

\section{2. $\boldsymbol{\alpha}$-オキシ酸， $\boldsymbol{\alpha}$-オキソ酸からアミノ酸の生成}

DL-rーメチルメルカプトームーオキシ酪酸から L-メチオ ニンが得られる ${ }^{45)}$ ○ェニルピルビン酸の場合には，ア ミノ酸のアミノ基が転位し，アミノ基供与体として Lグルタミン酸，L-アスパラギン酸も利用される ${ }^{46)}$ (図 20)。

$$
\begin{aligned}
& \mathrm{CH}_{3}-\mathrm{S}-\mathrm{CH}_{2}-\mathrm{CH}_{2}-\mathrm{CH}-\mathrm{CO}_{2} \mathrm{H} \underset{\mathrm{OH}}{\stackrel{\text { Bacillus }}{\text { Pseoudomonas }}} \\
& \mathrm{CH}_{3}-\mathrm{S}-\mathrm{CH}_{2}-\mathrm{CH}_{2}-\mathrm{CH}-\mathrm{CO}_{2} \mathrm{H}
\end{aligned}
$$

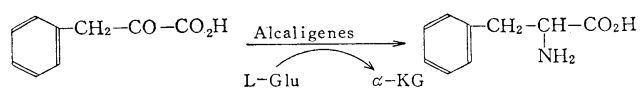

図 20

$\alpha-\mathrm{KG}: \alpha-$ ケトグルタル酸

インドールピルビン酸もアンモニウム塩の存在下に 50〜60\% の収率でアミ)化される ${ }^{47}$ （図 21）。

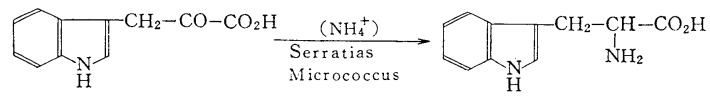

図 21

アントラニル酸やインド 一ルを先駆物質とする方 法が工業的には興味深 い。この経路には生合成 からのセリンが使われて いる48（図 22）。

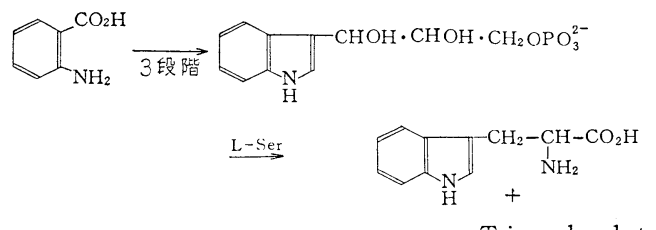

図 22 


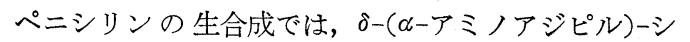
ステイニル・バリンで, システインの $\beta$-メチレン基が 脱水素されて特有の $\beta$-ラクタム環のできる酵素系があ る $^{49)}$ (図 23)。

$\alpha-\mathrm{Aad}=\alpha \cdot$ $=/$ アジピン酸
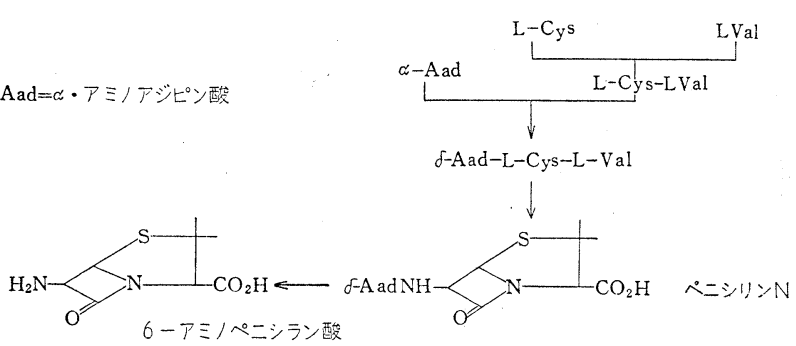

図 23

3. プリン環生成における発酵と合成 イノシン酸 のプリン塩基のC 2 位の炭素は有機合成反応によって も，生合成反応によってもギ酸が使われる。

生合成系ではイノシン酸から $\mathrm{IMP} \rightarrow \mathrm{XMP} \rightarrow \mathrm{GMP}$ と 逐次酵素反応で C 2 位にアミノ基が導入されてグアニル 酸になる。工業的には微生物によってヌクレオシドの代 謝中間体である AICAーリボシドを蓄積させる。

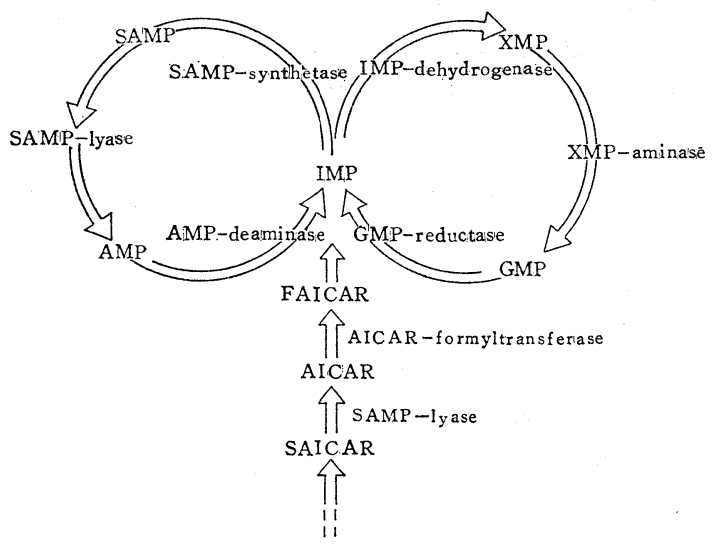

図 24 プリンヌクレオチド生合成経路

培養液から分離した AICA-リボシドとメチルキサン トゲン酸ナトリウムを反応させて合成化学的にプリン環 を形成させ，2-メルカプトイノシンが得られる。つぎに このメルカプト基を過酸化水素で酸化し，酸化物をその ままアンモニアで処理してグアノシンを合成する。グア

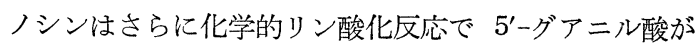
得られる ${ }^{50)}$ 。

このように AICA リボシドが発酵で効率よく蓄積さ れ，合成原料として利用できるようになってグアノシン の他に種々の 2-置換ヌクレオシドが多角的に 合成され た。2-メルカプトイノシンを過酸化水素酸化したのち,
アルキルアミンと反応させて N²-アルキルグアノシンが容 易に合成される（図 26）。ま た2-メチルメルカプトイノ シンを硫酸ジメチ ルで処理すると, 2-メチルチオイノ シンが得られる。 AICA-リボシ ドと有機酸エステ ルとの反応で $2-$ アルキルイノシン が合成できる ${ }^{51)}$

(図 27)。

このようなヌクレオシドは 無保護のまま $5^{\prime}$-水酸基に選 択的にリン酸化して $5^{\prime}$-ヌク レオチドとすることができ る $^{52)}$ 。2-置換ヌクレオチドの 呈味力をグルタミン酸ナトリ ウムとの相乗効果で比較した (表 2)。イノシン酸との呈味 力の比較は味の発現と化学構 造の関係をさぐる上できわめ て興味深い。プリン塩基の 2 位置換基のかたち，大きさ， 塩基度, 塩基とリボースの立 体配置などが呈味力に関係し ていると考えられるが，さら にアナログを合成して検討す ることにより呈味発現の機構 が解明されよう51)。
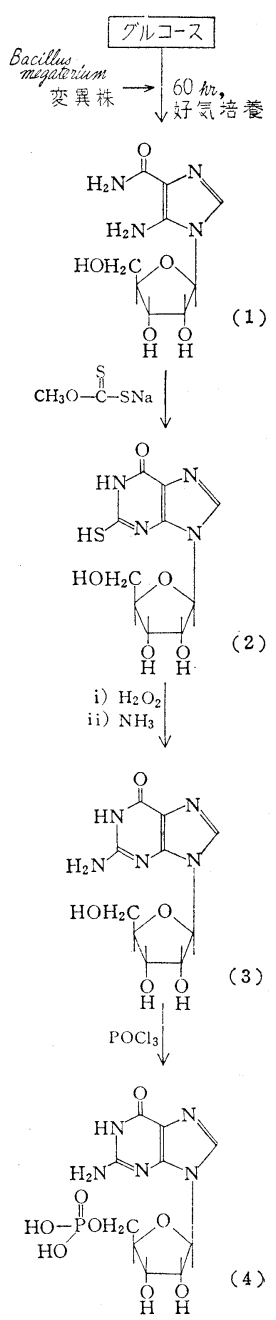

図 $25 \quad 5^{\prime}$-グアニル酸 の製法
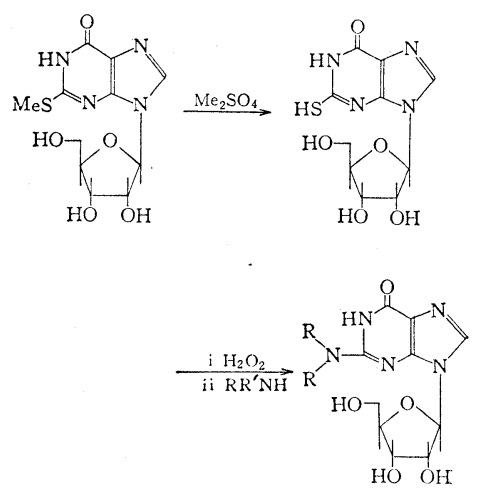

図 26 


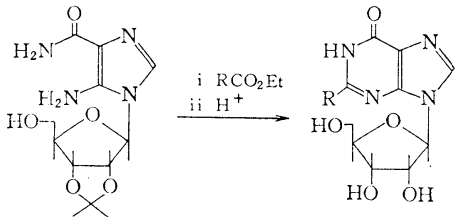

図 27

表 2 2-置換ヌクレオチドのグルタミン酸ナ トリウムとの呈味相乗勃果の比較 ${ }^{51}$

\begin{tabular}{|c|c|c|}
\hline ヌクレオチド & 呈 味 強 & 度 \\
\hline $5^{\prime}-\mathrm{IMP} 2 \mathrm{Na} \cdot 7.5 \mathrm{H}_{2} \mathrm{O}$ & $\mathrm{X}=-\mathrm{H}$ & 1.0 \\
\hline $5^{\prime}-\mathrm{GMP} 2 \mathrm{Na} \cdot 7 \mathrm{H}_{2} \mathrm{O}$ & $-\mathrm{NH}_{2}$ & 2.3 \\
\hline 2-Methylthio-5'-IMP $2 \mathrm{Na} \cdot 6 \mathrm{H}_{2} \mathrm{O}$ & $-\mathrm{S}-\mathrm{Me}$ & 8.0 \\
\hline 2-Ethylthio--5'-IMP $2 \mathrm{Na} \cdot 2 \mathrm{H}_{2} \mathrm{O}$ & $-\mathrm{S}-\mathrm{Et}$ & 7.5 \\
\hline $\mathrm{N}^{2}-$ Methyl-5'-GMP-2 Na $5.5 \mathrm{H}_{2} \mathrm{O}$ & $-\mathrm{NHMe}$ & 2.3 \\
\hline $\begin{array}{l}\mathrm{N}^{2}, \mathrm{~N}^{2}-\mathrm{Dimethyl}-5^{\prime}-\mathrm{GMP} 2 \mathrm{Na} \\
\quad 2.5 \mathrm{H}_{2} \mathrm{O}\end{array}$ & $-\mathrm{N}(\mathrm{Me})_{2}$ & 2.4 \\
\hline 2-Methyl-5'-IMP $2 \mathrm{Na} \cdot 6 \mathrm{H}_{2} \mathrm{O}$ & $-\mathrm{Me}$ & 2.3 \\
\hline 2-Ethyl-5'-1MP $2 \mathrm{Na} \cdot 1.5 \mathrm{H}_{2} \mathrm{O}$ & $-\mathrm{Et}$ & 2.3 \\
\hline
\end{tabular}

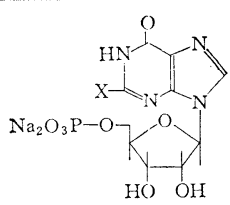

現在工業的に採用されている核酸系調味料の製法を （図 28）にまとめて示した。

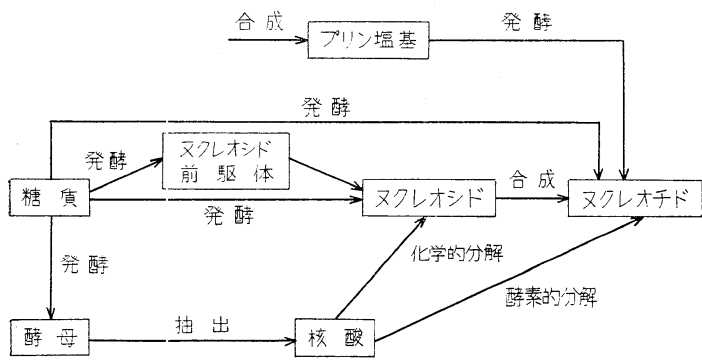

国 28 核酸系調味料の各種製造法略図 にこでいらヌクレオンドはプリン塩基と $\mathrm{D}$-リポースの 結合物，ヌクレオチドはさらにリン酸が結合した呈味性を 有する化洽物のこと)

アデニンは核酸系調味料を製造する上で，発酵培地の 栄養因子とし、て重要であり実際に使われている。また医 薬やその他の合成中間体としての需要も拡大してきてい る。アデニンの合成法はマロンニトリルなどから数工程 を経る複雑な方法にたよっていたが最近シアン化水素か ら一段階でアデニンが得られ ${ }^{53)}$ ，工業的に製造されてい る。この方法は宇甶化学的な反応条件ともいえるもので きわめて興味深い（図 29）。

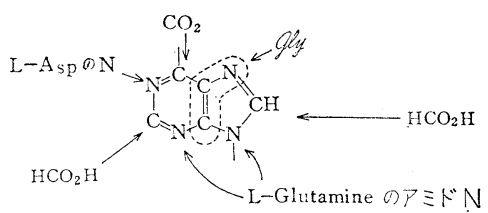

図 29

プリン環の生合成

アデニンは生合成系ではグリシンを主軸に生合成され るが（図 30）1961 年，シアン化水素のアンモニア水溶 液を加熱してアデニンを得た Oró の発見は画期的であ った ${ }^{54)}$ 。その後, 原始地球環境を想定した, メタン, ア ンモニア，水蒸気に電子線を照射してアデニンが生成す ることが知られた ${ }^{55)}$ 。アアン化水素を液体アンモニア系 で反応させることによって $23 \%$ に収率があがり工業的 な価值をもつに至った。

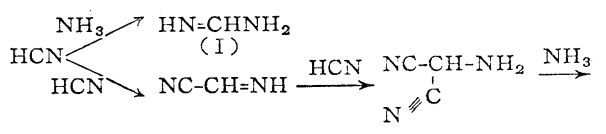

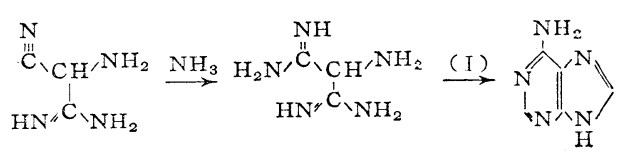

図 30 液体アンモニア中での $\mathrm{HCN}$ より アデニンの生成

原始の海での有機化合物の生成機構を追究するグルー プから最近巧みなヌクレオシドの合成法が生み出され $た^{56)}$ 。シトシンアラビノシドは, 膀胱ガン, 急性白血病 の治療に期待されている。アメリカの FDA も最近 prescription drug として承認し, 1969 年 10 月 Upjohn 社から Cytosar の名で市場に登場した。Orgel らは, メタンと窒素を火花放電下で反応させて，シアノアセチ レンが生成することを認め, 同時に尿素, シアン酸ナトリ ウム, あるいはジシアンなどの存在で, シトシンが生成す ることを見出した。この反応にリボースを添加しておく

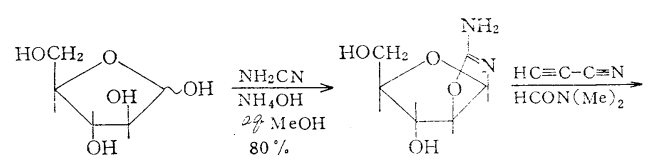

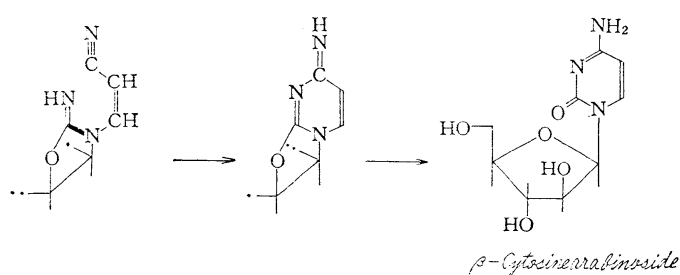

図 31 
と低收率ではあったがシチジンが生成した。しかし尿素 などの代りにシアナミドを使うと収率は非常に向上し た。この反応を実用的な条件で行なうと $64 \%$ の収率で シトシンアラビノシドが得られ，このものは選択的に $\beta$ 配位のヌクレオシドとして得られた（図 31）。

\section{V. 生体高分子に対する合成化学反応}

選択的な化学反応 ${ }^{57}$ や酵素反応 ${ }^{58}$ 学使って核酸 ${ }^{59}$ や酵 素を化学的に修飾する試み注分子間相互作用や触媒活性 の解明に重要な手法である。酵素の工業用, または医薬 用への応用も進み新しい用途がひらけてきた。合成高分 子にいろいろな酵素を結合させ, 半透膜のマイクロカプ セルに封じて治療目的に使う研究も進められている ${ }^{60)}$ 。 リボヌクレアーゼをへキサメチレンジイソシアナートで 架橋した場合には 1 モルの架橋では活性が残るが，熱， アルカリに対する耐性はかわらなかった リアルキルアミンオキシドでタンパク質を処理する方法 も知られている。リボヌクレアーゼをアルブミンなどと 4, 4'-ビスジアゾベンジジンで結合させ, 生体に臟器を移 植するときの免疫抑制剂に使う方法も出願されて抢り, 化学的処理や, 化学的修飾の方法が応用面でも発展し始 めている。

\section{VI. おわりに}

科学の進歩と共に領域の細分化が㧍こっている昨今, 化学工業の分野に扔いても生物あるいは有機化学的プロ セスを組み合わせて，それらを一つのシステムとしてと らえる方向が指向されるにちがいない。

微生物体内に沶注複雑な生合成反応による生成物は 巧みな情報処理の産物であり, 多くの反応を一つのシス テムの中に収为たものといえる。

しかしながら当然，原料から生産物までに関与する醳 素系が単純である程収率はよく, 複雑なときには中間生 成物がバイパスに流れたり, 代謝過程の調節回路の影響 が出たりして，目的物の收率がなかなか向上しない。

このような場合に合成有機化学的手法と組み合わせる ことによりプロセスを短かくすることは生産性の向上と いら面できわめて都合よく, 微生物のもつ生合成反応シ ステムをもら一つ次元の高いところで制御することにも なる。とくにわが国の化学工業の中で発展が期待される ファインケミカルの分野に目をむけると，こうした高度 の手法を利用し, 巧みな組み合わせによって複雑な化合 物をつくり出すこと澺義染いことでありまた今後の 発展が期待される。

また有機化合物の力による微生物の改良で新しい反忘
系や，能率のよい反応系が利用できることも期待され， さらには新しい合成反応を発酵プロセスに連結してより 経済的な工業，あるいは地域環境を污染することのない 理想的な, 社会的に意義深い化学工業に発展させること も可能ではなかららか。

本稿作製㐫たり, 味の素(株)中央研究所, 熊代, 奥 村両博士の助言を得た，ここに厚く謝意を表する。

(昭和 45 年 2 月 12 日受理)

\section{文献}

1) 竹西, 宮前, 化学工業 20 (1) 38 (1969); 金子, 日化協 29 (2) 90 (1969)

2) 日野, 明石, 太田，有合化 25349 (1967)

3) Anon, Chem. Age (June 6) 11 (1969)

4) Anon, Feed Stuffs 40 (39) Sept 28, 4 (1968)

5) Anon, Feed Stuffs 41 (5) Feb 1, 35 (1969)

6) 中森, 佐野, 椎尾, 昭 44 日本農化大会 No. 710 (1969)

7) 佐野, 椎尾, 昭 44 日本農化大会 No. 706 (1969)

8）宇田川, 阿部, 木下, 醗酵工業 40614 (1962); 滰波, 釣, 岡田, 小松, 大沢, 山本, 第 9 回了ミ ノ酸・核酸集談会

9) N.L. Somerson, T. Phillips, 日特公 昭 37-1695 (1962)

10) H.G. Khorana, Pure and Applied Chem. 17 349 (1968)

11) 吉川, 他, 科学 30419 (1968); 西村, 高分子 18 834 (1969); 池原, ファルマシア 5831 (1969); 木下, 日化協 21426 (1968)

12) N.O.V. Zondag, J. Am. Oil Chemists'Soc. 451 (1968)

13) J.E. Stewart, R. E. Kallio, D.P. Stevenson, D. O. Shissler, J. Bacteriol. 78441 (1959)

14) H. Iizuka, M. Iida, Y. Onami, J. Gen. Appl. Microbiol. 78441 (1959)

15）高橋， 42 年度農化大会要旨 p. 313 (1967)

16）荒井，山田，43年度農化大会要旨 No. 725 (1968)

17) J. Stewart, W.R. Finnerty, R.E. Kallio, Science 1321254 (1960)

18) J.W. Foster, T. Ishikura, Nature 192892 (1961)

19) Mobil Oil Corp, USP 3,326,772 (1967)

20）高山，阿部，木下，日本醴酵工学会 p. 65 (1969)

21) H.E. Reeves, R. Ralrin, W.S. Wegener, S.J. Ajl, Ann. Rev. Microbiol. 21225 (1967); K. Bloch, Acc. Chem. Res. 2193 (1969)

22) G.J. Scheroepfer, K. Bloch, J. Biol. Chem. 240 54 (1965)

23) E.J. Corey, W.L. Mock, D.J. Pastro, Tetrahedron Letters 347 (1961)

24) S. Dagley, W.C. Evans, Nature 188560 (1960)

25) J.B. Davis, R.L. Raymond, Appl. Microbiol. 9383 (1961)

26) R.L. Raymond, Appl. Microbiol. 15857 (1967)

27）大森, 堀口, 山田, Agr. Biol. Chem. 311337 (1967) 
28) A. Ichikawa, K. Adachi, K. Hosokawa, Y. Takedia, J. Biol. Chem. 2372296 (1962)

29) D.T. Gibson, Science 1611093 (1968)

30) S. Dagley, P.J. Chapman, D.T. Gibson, J.M. Wood, Nature 202775 (1964)

31) J. Davis, R.L. Raymond, USP 3,383,289 (1968)

32) D.F. Wessley, A.C.S. 154th meetings in Chicago (1967)

33）石倉, 西田, 丹野, 宮地, 尾崎, 日特公 昭 436991 (1968)

34) 中村, 小口, 石油学 12612,620 (1969)

35) 三村, 川野, 山家, 醗工 47603 (1969)

36）福岡，三上，伊藤，醗工 43381 (1965)； 44400 (1966)

37）清水, 田口, 醴工 47639 (1969)

38) Y. Murooka, T. Harada, J. Agr. Biol. Chem. 311035 (1967)

39) D.T.O. Wong, S.J. Ajl, J. Am. Chem. Soc. 783230 (1956)

40) W.S. Wegener, P. Fumanski, S.J. Ajl, Biochem. Biophys. Acta 14434 (1967)

41) H. Strassman, A.J. Thomas, L.A. Locke, S. Weinhouse, J. Am. Chem. Soc. 78228 (1956)

42) J.B. Búlock, The Biosynthesis of Natural Product (1965)

43）木下, 中山, 北田, 醗酵協誌 16517 (1958); 北 原, 福井, 三沢, 日特公 昭 38-6587; 農化 3444 (1960)

44）佐々木, 植村, 志村, 藤井, 日特公 昭 40-15955 (1965)

45）武末，日特公 昭 39-19150 (1964)
46) 朝井, 相田, 大石, Amino Acid 2114 (1900)

47) 相田, 朝井, 飯塚, 梶原, Amino Acid 194 (1959)

48）照井, 江夏, 岡崎, 醗酵工業 40120 (1962)

49) A.L. Demain, Biosynth. of Antibiotics I 29 (1966)

50) 竹西，杉田，化学と工業 21197 (1968)

51) I. Kumashiro, Biotech. Bioeng. 10303 (1968)

52) M. Yoshikawa, T. Kato, T. Takenishi, Tetrahedron Letters 5065 (1967); Bull. Chem. Soc. 423505 (1969)

53) H. Wakamatsu, Y. Yamada, T. Saito, I. Kumashiro, T. Takenishi, J. Org. Chem. 312035 (1966); Chem. Eng. News 44 No. 32, 39 (1966)

54) J. Oró, A.P. Kimball, Arch. Biochem. Biophys. 94217 (1961)

55) C. Palm, M. Calvin, J. Am. Chem. Soc. 84 2115 (1962)

56) Anon, Chem. Eng. News 47 (42) 30 (1969)

57) 大井, 生体高分子 I (生物物理学講座 4) 229 (1965); 殿村，J. Biol. Chem. 337366 (1962); Biochim. Biophys. Acta 82833 (1964); J. Biochem. 61555 (1967); 60476 (1966)

58) 徳重, 化学 23191 (1968)

59）入江，化学と生物 4597 (1966)

60) Anon, Chem. Eng. News 47 (40) 44 (1969)

61) 小沢, 日本醗酵工学会講演要旨 174 (1969)

62) A. Daniel Midland Co., USP 3,320,078 (1967)

63) Ashland Oil and Ref Co., USP 3, 356, 518 (1967)

64) Natl.Res. Dev.Corp., 蘭公開 6,713,780 (1968)

\section{お 知 らせ}

昨年暮に発行しました「会員名簿 (130ページ)」が若干残っております。入手ご希望の方は下 記代金を添えてお申出下さい。本会々員名簿は実用面を主眼に編集しましたので大変使い易いと 存じます。

たとえば氏名, 会員番号, 出身校, 卒業年次, 勤務先, 自宅の順に挙げ，勤務先と自宅の所在 地には特に郵便番号と電話番号をも収録してあります。またこのほか本会の沿革や定款，諸規定 等も揭載しましたので奮ってご利用下さい。

\section{記}

本会会員は 頒価 1 冊

200 円・送料 65 円（現金または小為替）

非会員は

1 冊

500 円（送料共） 